\title{
Research Article: Studies on heterosis for yield and yield components in okra (Abelmoschus esculentus L.)
}

Article Chronicle: Received :

12.07.2017;

Accepted :

25.07.2017

KeY WoRds:

Germplasm lines,

Full-diallel progenies, Heterotic pattern, Mean performance
Author for correspondence :

RAMESHKUMAR Department of Horticulture (Vegetable Science) Tamil Nadu Agricultural University, COIMBATORE (T.N.) INDIA

See end of the article for authors' affiliations

\section{口 RAMESHKUMAR, GUNASEKAR AND MANIMARAN}

SUMMARY : Okra [Abelmoschus esculentus (L.) Moench], being an often cross-pollinated crop, responds well toheterosis breeding. Exploitation of heterosis is primarily dependent on the screening and selection of available germplasm that could be produced by better combinations of important agronomic characters. Six elite, optimally divergent and nearly homozygous lines of okra namely $\mathrm{P}_{1}$ (Arka Abhey), $\mathrm{P}_{2}$ (Pusa-A4), $\mathrm{P}_{3}$ (Arka Anamika), $\mathrm{P}_{4}$ (EC-755647), $\mathrm{P}_{5}$ (EC-755648)and $\mathrm{P}_{6}(\mathrm{EC}-755654)$ selected from the germplasm were crossed in all possible combinations including reciprocals during summer 2014. The resultant $30 \mathrm{~F}_{1} \mathrm{~s}$ along with their 6 parents and one commercial check (Arka Anamika) were evaluated in a Randomized Block Design with two replications during mid Kharif(August - October), 2014 at the Adhiparasakthi Horticultural College, Kalavai, Vellore, Tamil Nadu,India. Heterosis over mid parent, better parent and standard check were studied for 10 quantitative characters pertaining to pod yield and its associated characters. For total yield per plant, the crosses as a whole manifested $21.42 \%$ and $22.48 \%$ average and standard heterosis, respectively. The crosses Arka Abhey x EC-755648 $\left(\mathrm{P}_{1} \times \mathrm{P}_{5}\right)$ and EC-755648 x EC-755654 $\left(\mathrm{P}_{5} \times \mathrm{P}_{6}\right)$ manifested significantly negative commercial heterosis for days to first flowering $(-2.26 \%)$ and fruiting nodes $(-12.82 \%)$, respectively, indicating their earliness. Highest heterobeltiosis of $16.54 \%$ for total yield per plant was manifested by the cross EC-755654 x Arka Abhey $\left(\mathrm{P}_{6} \times \mathrm{P}_{1}\right)$. The extent of standard heterosis for total yield per plant $(22.48 \%)$ appears to be sufficient for exploitation of heterosis commercially. The crosses Arka Anamika x EC-755648 $\left(\mathrm{P}_{3} \times \mathrm{P}_{5}\right)$ and EC-755647 x EC-755648 $\left(\mathrm{P}_{4} \times \mathrm{P}_{5}\right)$ were statistically on par with the standard check in their mean performance and are as promising as that of the standard check (Arka Anamika).

How to cite this article : Rameshkumar, Gunasekar and Manimaran (2017). Studies on heterosis for yield and yield components in okra (Abelmoschus esculentus L.). Agric. Update, 12(TECHSEAR-2) : 547-553; DOI: 10.15740/HAS/AU/12.TECHSEAR(2)2017/547-553. 